\title{
O IRAJÁ JÁ TEVE MAR: A EXPERIÊNCIA DO IRAJÁ ATLÉTICO CLUBE (RIO DE JANEIRO, 1912-1938)
}

\author{
IRAJÁ ALREADY HAD SEA: THE EXPERIENCE OF IRAJÁ \\ ATLÉTICO CLUBE (RIO DE JANEIRO, 1912-1938)
}

\author{
Prof. Dr. Victor Andrade de Melo ${ }^{1}$ \\ Prof. Ms. Rafael Mattoso 2
}

\begin{abstract}
RESUMO: Partindo do princípio que as trajetórias das agremiações esportivas são indicadores dos processos de urbanização, este artigo objetiva discutir a experiência do Irajá Atlético Clube, associação sediada numa das áreas mais antigas do Rio de Janeiro. Considerando o interesse na repercussão pública das suas iniciativas, para alcance do objetivo, como fontes, foram utilizados periódicos. Como recorte temporal, adotou-se seu ano de fundação (1912) e o momento no qual se percebe uma mudança em seu perfil com a redução da importância do futebol em seu funcionamento (1938). Espera-se lançar um olhar original para uma região pouco investigada, ampliando as percepções históricas sobre a cidade, em geral muito centradas nas zonas ditas privilegiadas.
\end{abstract}

PALAVRAS-CHAVE: História do Rio de Janeiro. História do Esporte. Subúrbio

ABSTRACT: Considering that the trajectories of sporting associations are indicators of the urbanization processes, this article aims to discuss the experience of Irajá Atlético Clube, an association that was founded in one of the oldest regions of Rio de Janeiro. As we are interested in the public repercussions of its initiatives, in order to reach the objective, newspapers and magazines were used as sources. As a time frame, it was adopted its foundation year (1912) and the moment when a change in its profile is perceived with the reduction of the importance of football in its functioning (1938). It is expected to take an original look at a region that has been little investigated, expanding historical perceptions about the city, usually centered in the so-called privileged areas.

\footnotetext{
${ }^{1}$ PPGHC/Universidade Federal do Rio de Janeiro. Email: victor.a.melo@uol.com.br. Orcid: http://orcid.org/0000-0002-1983-1475.

2 Doutorando do Prourb/Universidade Federal do Rio de Janeiro. Email: rafaelmattoso@yahoo.com.br. Orcid: https://orcid.org/0000-0001-8493-932X.
} 
KEYWORDS: Rio de Janeiro History. Sport History. Suburb

\section{Introdução}

Há algumas regularidades na história recente da ocupação dos subúrbios do Rio de Janeiro, processo que se tornou mais notável a partir dos anos finais do século XIX e décadas iniciais da centúria seguinte. Em geral, propriedades agrícolas foram sendo loteadas e ocupadas por gente de diversos estratos sociais, adensando-se antigos e constituindo-se novos núcleos populacionais. Facilitou e mesmo induziu tal desenvolvimento, a instalação de linhas férreas, iniciada em 1858. A importância desse meio de transporte foi se ampliando no decorrer do tempo em função da construção de novos ramais e estações, bem como da melhoria dos serviços (ABREU, 1987).

A nova alternativa de transporte, a qual se adendaram linhas de bonde, atendeu gente de estratos populares e camadas médias que sentiram de forma cada vez mais intensa dificuldades de se manter morando na região central gentrificada em função de reformas urbanas que buscaram adequar o Rio de Janeiro a ideais de civilização e progresso cuja inspiração vinha de países europeus. Nos bairros do subúrbio ${ }^{3}$, todavia, também foram viver famílias de estrato socioeconômico mais alto devido à instalação de iniciativas fabris e comerciais diversas.

A despeito da heterogeneidade e dinamismo socioeconômicos, a conformação da zona suburbana, assim oficialmente denominada desde o recenseamento de 1890 (MIYASAKA, 2016), foi marcada por um processo de estigmatização, a representação de que era o oposto dos padrões adotados na reestruturação da região central (FERNANDES, 1995). Há que se ter em conta que, efetivamente, os subúrbios receberam menor atenção, incentivos e investimentos do poder público (ABREU, 1987).

\footnotetext{
${ }^{3}$ A cidade era organizada em Freguesias, posteriormente em Distritos e depois em Regiões Administrativas. Os bairros só foram oficialmente delimitados em 1981. Bem antes, contudo, se estabeleceram como importantes espaços citadinos. Segundo Soares (1990: 105): “A noção de bairro é uma noção de origem popular, tirada da linguagem corrente. (...). Ela se baseia num sentimento coletivo dos habitantes (...)".
} 
Frente a tal cenário, boa parte do desenvolvimento da zona se deveu a investimentos de uma elite local que se forjara, iniciativas que tinham em conta melhorar as condições de urbanidade, bem como combater os estigmas. Devese ter em conta o perfil dessa elite local, por Lima Barreto chamava de “aristocracia suburbana “ (SANTOS JUNIOR, 2017): lograva destaque e liderança nos subúrbios, mas não necessariamente nas áreas mais privilegiadas da cidade, com as quais dialogava e procurava ter em conta na estruturação de suas ações.

Tratou-se de um processo de trânsito cultural, intenções de, em certa medida, emular determinados parâmetros de modernidade que conferiam prestígio à região central da cidade e novas áreas de expansão da zona sul. Não se deve, contudo, o considerar como uma relação linear centro-periferia. Havia assimetria de poder, mas as lideranças do subúrbio, bem como a população em geral, foram ativas nesse cenário de apreensão ${ }^{4}$. Para além disso, deve-se considerar os condicionantes contextuais específicos. O que se gestou foram múltiplas experiências peculiares.

Temos em conta o que sugere Thompson, a importância da categoria experiência na medida em que "compreende a resposta mental e emocional, seja de um indivíduo ou de um grupo social, a muitos acontecimentos interrelacionados ou a muitas repetições do mesmo tipo de acontecimento" (1981, p. 15). Para o autor, é na relação complexa entre o que é pensado e vivido “assim como o ser é pensado, também o pensamento é vivido" (1981, p. 17) que os coletivos exercem uma postura ativa frente ao que lhes é imposto, gestando formas específicas de se portar no mundo ${ }^{5}$.

Fatores diversos - entre os quais a formação societária, a vocação econômica e a influência de aspectos geográficos, interferiram no processo de estruturação e desenvolvimento dos bairros, no forjar de perfis específicos. Essas peculiaridades também se identificam em outra regularidade observável

\footnotetext{
${ }^{4}$ A ideia de trânsito cultural enquanto um processo ativo de recepção é trabalhada a partir de Canclini (1997). A noção revista de relação centro-periferia tem em conta o diálogo de Maia (2019).

${ }_{5}^{5}$ Para um debate mais aprofundado sobre as categorias experiência e peculiaridades em Thompson, ver Negro e Silva (2001).
} 
na história dos subúrbios cariocas: a criação de agremiações, ocorrência usual onde há aumento populacional e diversificação socioeconômica. Mesmo, em geral, sendo liderados por gente de estratos médios e altos, muitos desses clubes lograram reconhecimento e legitimidade local.

As agremiações esportivas desempenharam papel importante na constituição dos subúrbios. Para além de se tornarem notáveis espaços de sociabilidade, funcionaram como agências de inserção dos bairros no grande concerto da cidade, uma forma de demonstrar a adesão a padrões de modernidade. Ao mesmo tempo, apresentavam para a população local, a partir do olhar das lideranças, comportamentos julgados adequados para estruturar o cotidiano (MELO, 2021).

Como sua atuação foi sempre negociada - as iniciativas de dirigentes tinham que considerar e dialogar com o conjunto da população, as experiências esportivas funcionaram como importantes estratégias de urdimento de uma identidade local que poderia ser esgrimida não somente no que tange a representações oriundas do centro como também no tocante às próprias disputas suburbanas (MELO, 2020a; MELO; SANTOS JUNIOR, 2020).

Nesse sentido, os clubes foram, simultaneamente derivados e agentes relevantes na "produção do espaço", na direção do que sugere Lefbreve (2006). O bairro, por si só, não existe, é constituído pelos mais distintos fatores (SOARES, 1990). As agremiações participaram desse cenário de estruturação produto e produtores.

Tendo em vista essas observações, este estudo tem por objetivo discutir a experiência do Irajá Atlético Clube, agremiação sediada numa das áreas mais antigas do Rio de Janeiro (Irajá). De pronto, saltou aos olhos uma peculiaridade. Ainda que na região tivesse se estabelecido no passado uma forte relação com o mar, no bairro não se estruturaram iniciativas de esportes náuticos, como houve nos vizinhos Ramos, Penha e Olaria (MELO, 2020a, 2020b).

Imagem 1 - Porto Velho de Irajá, 1919. 


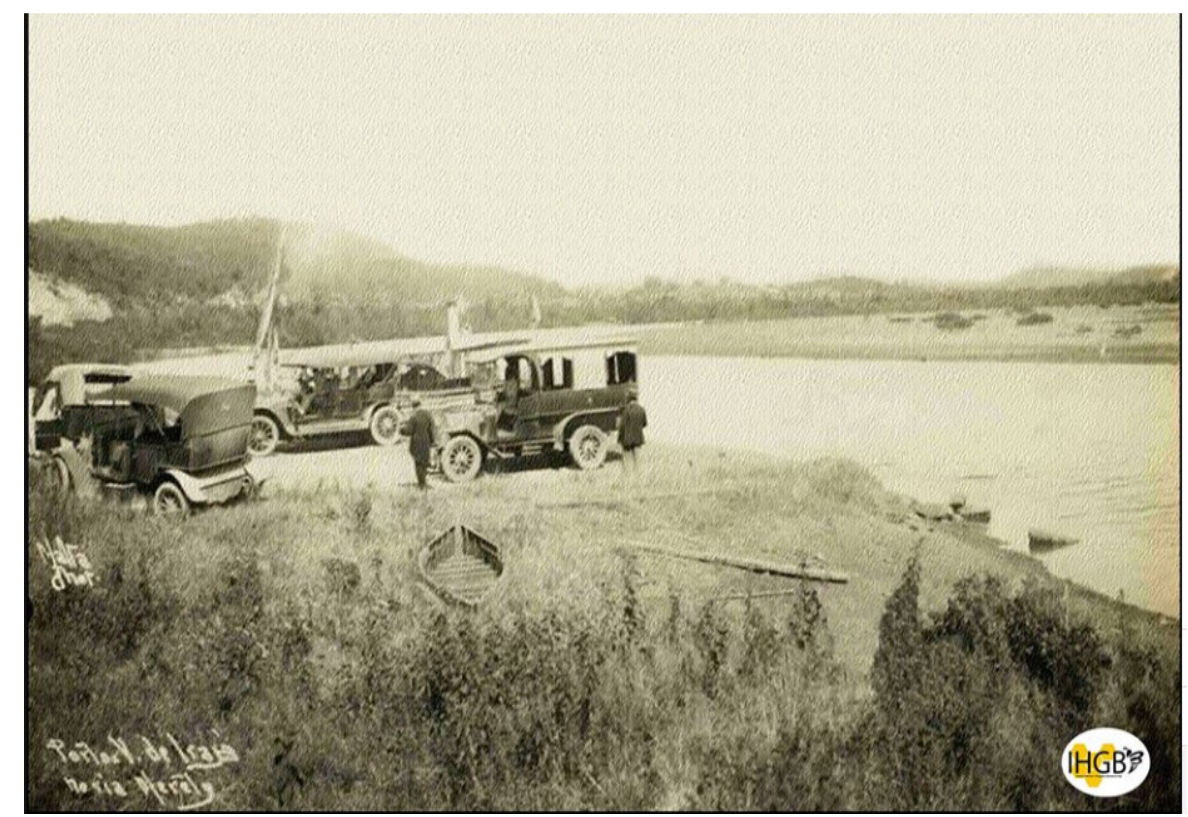

Fonte: Instituto Histórico e Geográfico Baixada de Irajá. Disponível em:

https://www.facebook.com/IHGBI.oficial/photos/a.664033573767895/1267443173426 929/?type $=3 \&$ theater

Como hipótese inicial, sugerimos que foi determinante para tal a influência de iniciativas estruturadas em Madureira, onde o campo esportivo já vinha se conformando desde a década final do século XIX (MELO; SANTOS JÚNIOR, 2020). A propósito, para estabelecer um contraponto com a experiência do Irajá Atlético Clube, abordaremos a breve trajetória (1929-1935) do Guanabara Tênis Clube, criado nas redondezas, no vizinho bairro de Brás de Pina.

Tendo em conta o interesse na repercussão pública das iniciativas do Irajá Atlético Clube, para alcance do objetivo, como fontes, foram utilizados periódicos publicados no Rio de Janeiro. Como recorte temporal, adotou-se seu ano de fundação (1912) e o momento no qual se percebe uma mudança em seu perfil com a redução da importância do futebol em seu funcionamento (1938).

Há de se ter em conta o perfil do bairro de Irajá. Nos dias de hoje, quem passa por suas ruas, dificilmente perceberá sua importância histórica para o Rio de Janeiro. O grande crescimento da região acabou por ocultar marcos que são anteriores mesmo à fundação da cidade. 
Em 1644, o Irajá tornou-se a primeira freguesia rural do Rio de Janeiro, tendo sido de grande relevância no tocante à ocupação dos então chamados sertões cariocas ${ }^{6}$. Àquela altura, a região já era marcada pela existência de importantes propriedades agrícolas, entre as quais o Engenho da Nossa Senhora da Ajuda e a Fazenda do Engenho da Pedra (GERSON, 1965).

A institucionalização da freguesia teve relação com a necessidade de maior controle da área produtora de gêneros agrícolas destinados tanto ao abastecimento interno quanto ao mercado internacional. No decorrer do tempo, tornaram-se conhecidos engenhos como o Sacopema, o Portela e o Brás de Pina. A importância do Porto de Irajá, por onde era escoada a produção, foi largamente registrada por historiadores e memorialistas.

A região começou a se tornar mais urbanizada a partir dos anos 1850 , quando as antigas grandes propriedades começaram a ser loteadas, vendidas ou alugadas. Segundo Pechman (1985: 143): “Abrindo caminhos para construir novos bairros, centenas de novos arruamentos começaram a cortar as antigas chácaras suburbanas, condição necessária para o desencadeamento do processo de produção de moradias".

Segundos dados coligidos por Abreu (1987), entre 1872 e 1890, a Freguesia de Irajá teve um aumento de mais de 120\% (passou de 5.910 para 13.130 habitantes). Em 1906, o Distrito voltou a crescer mais de 100\% (chegou a 27.140). Em 1920, percebe-se um salto de incríveis $263 \%$, tornando-se, com 99.586 moradores, o segundo mais habitado dos subúrbios e da cidade (atrás somente de Inhaúma).

A região era marcada por grande heterogeneidade socioeconômica, habitada por populares, mas também por gente de estratos médios e altos que trabalhava nos empreendimentos comerciais e industriais que por lá se instalaram, bem como por funcionários públicos que atuavam nos mais diferentes ramos da administração. Muitos desses integraram uma elite local

\footnotetext{
${ }^{6}$ Era uma grande área que foi sendo dividida dando origem a novas freguesias: "Jacarepaguá, desmembrado em 6 de março de 1661; Campo Grande, desmembrado em 1673; Inhaúma, em 27 de janeiro de 1743, e Engenho Velho, em 1795" (ABREU, 1987: 78).
} 
que entabulou relevantes ações em prol do desenvolvimento do bairro, entre as quais a fundação do Irajá Atlético Clube.

Vale destacar que as agremiações esportivas são expressões das peculiaridades dos bairros não somente no que se refere às modalidades adotadas, como também no tocante ao perfil das lideranças envolvidas. Lançar um olhar sobre sua experiência é também refletir sobre o processo de urbanização do Rio de Janeiro, deslocando as percepções históricas muito centradas nas regiões ditas privilegiadas ${ }^{7}$.

\section{Irajá Atlético Clube: uma agremiação comunitária}

Em maio de 1893, um cronista se derramou em elogios a um "grupo de rapazes corajosos" (CLUBE...,18 jun. 1893: 3) que fundou o Clube Atlético de Irajá, provavelmente a primeira agremiação esportiva da Freguesia. A iniciativa, que tinha sede na fronteira entre Cascadura e Madureira ${ }^{8}$ (BOND, 30 jul. 1893: 1), era presidida por Edmundo Julio de Medeiros, personagem já envolvido com outras ações no âmbito do entretenimento e formação cultural, como a Sociedade Dramática 10 de agosto, instalada no Campinho, associação de amadores que se destacou por seu compromisso abolicionista (CAMPINHO, 28 dez. 1890: 3).

Medeiros era um amanuense da Estrada de Ferro. Outros dirigentes do Clube Atlético de Irajá trabalhavam nessa empresa, entre os quais Arthur de Vasconcellos Bittencourt, um dos responsáveis pela publicação de O Echo, um periódico suburbano que teve sede no bairro do Engenho Novo. Perceba-se, portanto, o perfil dos envolvidos com a iniciativa: gente engajada no desenvolvimento da região, adepta de noções de civilização e progresso.

A Sociedade Dramática promovia récitas, bailes e cursos de teatro. O Clube Atlético organizava corridas a pé, primórdios do atletismo. Era mais uma das agremiações dessa natureza que se espraiaram por vários bairros num momento em que a modalidade se tornou uma febre na cidade. No caso dos

\footnotetext{
${ }_{8}^{7}$ Para um debate sobre a importância de investigar o subúrbio, ver Maciel (2010).

${ }^{8} \mathrm{Na}$ ocasião, os dois bairros faziam parte da Freguesia de Irajá.
} 
subúrbios, foi tanto um sinal de crescimento populacional quanto um indício de que já havia movimentos de modernização (MELO, 2020c).

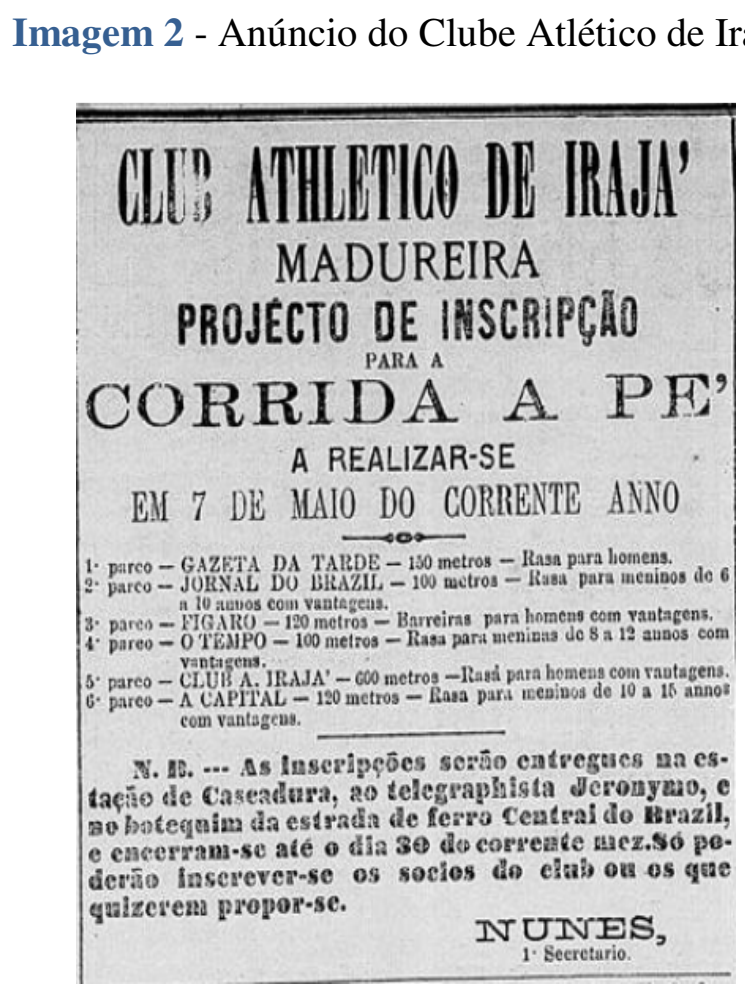

Fonte: Tempo, 27 abr. 1893: 4.

Aparentemente, o Clube Atlético de Irajá teve vida curta, ainda que animada. Os relatos sugerem que as arquibancadas contavam com bom público, inclusive pessoas do "risonho belo sexo" (SPORT, 23 jul. 1893: 3). Rapazes e meninas disputavam provas. Recriava-se no subúrbio um espetáculo moderno com todos seus padrões.

Madureira, portanto, tinha um movimento associativo que já estava se delineando desde o final do século XIX. Nos anos 1910, vários clubes esportivos foram criados no bairro, entre os quais dois notáveis, o Magno Futebol Clube (1913) e o Fidalgo Futebol Clube (1914), a primeira rivalidade da região. No Distrito, em 1912, fundou-se o Irajá Atlético Clube (DIÁRIO..., 16 fev. 1930: 44).

Antes, contudo, em 1909, foi criado o Clube de Irajá, uma sociedade dramática com sede na Estrada Marechal Rangel, atual Ministro Edgar Romero 
(TEATROS..., 30 abr. 1909: 3). Quem dirigia a agremiação eram "distintos proprietários e negociantes" (DIVERSÕES, 1 dez. 1910: 11) do bairro, alguns desses também envolvidos com a fundação do Irajá Atlético Clube.

Vale ter em conta que se tratou de um momento no qual houve na região notável avanço nos movimentos de organização política. Em 1911, foi criado o Comitê Central de Melhoramentos, "um dos primeiros fundados exclusivamente com a intenção de propugnar pelos interesses de um distrito da cidade" (MENDONÇA, 2017: 71). Nesse cenário, o novo clube esportivo se constituiu em mais uma esfera de articulação das lideranças locais.

Do ponto de vista esportivo, era grande a ambição dos envolvidos com sua criação: “Tem por fim a prática do futebol, atletismo, ginástica e outros para desenvolvimento físico de seus associados" (DIÁRIO..., 16 fev. 1930: 44). Seu intuito era distinto, por exemplo, ao do Olaria e do Campo Grande, que começaram como "Futebol Clube" e só depois se tornaram "Atlético Clube".

Da mesma forma, diferentemente de alguns clubes de Ramos e Penha, a agremiação de Irajá não se envolveu com modalidades náuticas, algo que pode ter se dado por pelo menos dois fatores, além da já citada influência das experiências de Madureira: na ocasião, o mar não era mais uma referência tão importante para o bairro; o perfil dos associados, não adeptos do remo e do iatismo. A propósito, registre-se que, nos subúrbios, as iniciativas ligadas a esses esportes somente ocorreram alguns anos depois, a partir de 1920, pioneiramente no Olaria Atlético Clube, (MELO, 2020a, 2020b)

Do ponto de vista de suas intenções, tratou-se de uma experiência mais próxima a do Mackenzie, que já nasceu como Sport Club. Como a agremiação do Méier, a despeito dos intuitos anunciados em seus estatutos, o Irajá Atlético permaneceu muitos anos somente dedicado ao futebol. Há entre os dois clubes, contudo, uma diferença: a sociedade irajaense demorou a se associar e teve pouca inserção nas ligas mais prestigiosas da cidade, mantendo-se a maior parte do tempo como uma afiliada de entidades suburbanas.

Àquela altura, a Liga Metropolitana de Esportes Atléticos (depois renomeada para Liga Metropolitana de Desportos Terrestres) era a mais 
prestigiosa da cidade, envolvendo os clubes com maior poder financeiro, boa parte deles estabelecidos nas zonas Centro e Sul, agremiações que procuravam restringir as possibilidades de participação e direção dos rumos do esporte no Rio de Janeiro, algo que ficou mais notável quando, em 1924, a partir de uma cisão, foi criada a Associação Metropolitana de Esportes Atléticos (SANTOS, 2010). Como contraponto, surgiram outras associações com o intuito de reunir as sociedades que não se adequavam ou desejavam aderir a essa forma de conceber a estruturação das iniciativas esportivas, entre as quais algumas sediadas nos subúrbios, como veremos mais adiante.

Nos periódicos, somente a partir de 1915, vemos notícias da nova agremiação, um indício de que teve um período inicial de estruturação no qual houve pouca repercussão na cidade. Não era uma exceção. Durante muitos anos, os clubes do subúrbio, assim como outros assuntos da região, obtiveram pouco espaço nos jornais e revistas de maior circulação 9 .

Somente a partir de meados dos anos 1910, tais periódicos passaram a dedicar maior atenção àquela região da cidade que crescia muito, proporcionalmente mais do que o centro (MIYASAKA, 2016). Entre outras mudanças, surgiram seções dedicadas aos subúrbios. No que tange aos clubes esportivos, alguns jornais se ofereceram para atuar como órgão oficial de comunicação, uma estratégia que atendia aos interesses de ambos, imprensa e agremiações.

Em 1915, o Irajá Atlético Clube adotou como órgão oficial O Imparcial (SPORT, 30 nov. 1918: 7), um periódico que dedicava grande atenção aos esportes e aumentou continuamente seu interesse pelos clubes e ligas suburbanas. Em 1927, foi escolhido para tal A Rua, jornal que passou a dar maior visibilidade aos assuntos do subúrbio, inclusive aos acontecimentos esportivos. Em 1929, A Manhã ocuparia esse posto. Perceba-se que mesmo que fossem modestos seus intuitos de inserção no campo esportivo mais prestigioso

\footnotetext{
${ }^{9}$ Uma decorrência dessa falta de atenção foi, inclusive, o surgimento de periódicos suburbanos nos quais as lideranças locais lançavam um olhar mais atento e crítico para os temas importantes da área. Para um debate sobre o tema, ver Mendonça (2017).
} 
da cidade, constantemente a agremiação irajaense teve em conta alguma projeção.

Segundo Agostinho Rodrigues ${ }^{10}$, a primeira sede social do Irajá Atlético se encontrava na Avenida Automóvel Clube, transferindo-se depois para a Estrada (futura Avenida) Monsenhor Félix (FUTEBOL, 16 jan. 1916: 9), na localidade conhecida como Pedreira, próximo à estação de trem. $\mathrm{O}$ clube buscou um espaço maior para instalar seu ground, condição fundamental para que integrasse alguma liga e participasse de campeonatos melhor estruturados.

Não surpreende, portanto, com esses investimentos, que o Irajá Atlético, em 1917, tenha se filiado à Associação Atlética Suburbana ${ }^{11}$. Criada em 1915, essa liga contava com outros seis clubes, inclusive o Magno e o Fidalgo de Madureira (bairro onde ficava a sede da entidade). Tratava-se de uma rival da Liga Suburbana, a principal dos subúrbios, uma das mais importantes da cidade $(\text { SANTOS, 2010) })^{12}$.

A inserção em um campeonato reconhecido era também parte do desejo de projeção do clube no bairro e na cidade como um todo. Por ocasião de um conflito ocorrido no campo do Fidalgo, quando um jornal anunciou equivocadamente que o problema se dera no Irajá Atlético, o presidente da agremiação fez publicar um comunicado contestando o fato, deixando claro que "até a data presente não teve ainda necessidade de nenhuma intervenção policial" (O FUTEBOL..., 22 jun. 1917: 4). Tratava-se de zelar pela representação civilizada que se buscava forjar, ainda mais no seu ano de estreia, quando se sagrou campeão do certame dos primeiros times.

\footnotetext{
${ }^{10}$ Rodrigues realizou uma ampla pesquisa sobre o bairro no qual viveu por muitos anos e atuou em vários âmbitos culturais, sendo inclusive fundador e presidente da Academia Irajaense de Letras e Artes. Seu estudo está disponível em: <http://iraja.jorgerodrigues.com.br/>. O material está também publicado em livro lançado, em 2012, pelo Instituto Histórico e Geográfico Baixada de Irajá.

${ }^{11}$ Além de investimento em instalações, a inscrição no campeonato de 1917 custou $30 \$ 000$ (ASSOCIAÇÃO..., 28 fev. 1917: 5). O valor não era tão elevado. Na mesma edição do jornal, percebemos que uma diária completa no célebre Hotel Avenida custava $10 \$ 000$ e a mensalidade de um curso preparatório para o Colégio Pedro II valia $20 \$ 000$ (p. 6). De toda forma, era mais um gasto que deveria prever a diretoria, junto com uniformes, equipamentos e deslocamentos para os jogos.

12 Segundo Santos (2010), nas décadas de 1910 e 1920, havia seis ligas atuando simultaneamente nos subúrbios. A Associação Atlética foi crescendo no decorrer do tempo, seus campeonatos tornando-se mais valorizados (SOUZA, 2018).
} 
No decorrer de sua história, contudo, o Irajá Atlético esteve envolvido em conflitos nos gramados. Em 1919, foi campeão do Torneio Início, realizado no campo da agremiação. No campeonato regular, esteve próximo de também se sagrar vitorioso, superado, contudo, no último jogo, pelo Fidalgo. Essa partida foi marcada por muita tensão. Segundo um cronista, "como se esperam graves acontecimentos, (...), as autoridades locais tomaram todas as providências no sentido de manter a ordem" (O CAMPEONATO..., $21 \mathrm{dez}$. 1919: 10). No policiamento, atuaram guardas civis, bem como militares de cavalaria e infantaria.

Esses episódios foram constantes na história do futebol, não só nos subúrbios, embora, quando nesses ocorriam, recebessem uma cobertura ainda mais crítica por parte da imprensa (SANTOS JUNIOR; MELO, 2013). O velho esporte bretão usualmente esgarçava os discursos civilizatórios. O calor das pugnas e das vinculações clubísticas não raramente se desdobravam em violência, condenada pelos que propugnavam que a prática esportiva deveria ser exemplo de progresso e ordem.

Nos anos iniciais do clube, destacou-se a atuação de Alcides Horta. O primeiro presidente ocupou, no decorrer do tempo, vários cargos na diretoria e foi usual árbitro nos jogos da Suburbana. Era despachante da Alfândega, uma liderança de estrato médio que tinha experiência e articulação em vários âmbitos.

Não surpreendentemente, se elegeu Pinto Machado como presidente honorário $^{13}$. Importante personagem do subúrbio, um dos líderes mais reconhecidos da região, jornalista em periódicos locais, cunhador do termo “inteligente meio suburbano" (MENDONÇA, 2017: 40), morador de Irajá, sua escolha para o título honorífico bem explicita os intuitos da agremiação ${ }^{14}$. Para além de ser um espaço de diversão, havia intenções de contribuir com a

\footnotetext{
${ }^{13}$ A diretoria de 1917 pode ser consultada em: NOS..., 21 ago. 1917: 6.

${ }^{14}$ Para mais informações sobre esse personagem, ver Mendonça (2017: 44). Segundo o autor, "as relações políticas que estabeleceu ao longo do tempo o levaram a ocupar postos da administração pública, como coronel da Guarda Nacional, $2^{\circ}$ suplente de polícia do $25^{\circ}$ distrito e administrador da Vila Proletária de Marechal Hermes".
} 
valorização do bairro, uma forma de demonstrar seus avanços, uma ferramenta para combater os estigmas.

A propósito, não foi a única vez que o Irajá Atlético teve alguém importante da imprensa como dirigente. Em 1927, assumiu a presidência Manuel Antunes Batista, jornalista que tinha forte relação com as causas suburbanas, responsável pelas seções esportivas de A Época e A Tribuna, usual participante de jogos de futebol na condição de árbitro, bem como de agremiações como dirigente. Era uma liderança política da região.

Quem eram os jogadores do Irajá Atlético Clube? Entre outros, Ildefonso Bastos, um conhecido dinamizador de agremiações carnavalescas, também praticante de várias modalidades. Urbano Burlier era mecânico da Estrada de Ferro Central do Brasil, assim como Raulino de Paula Bastos, dirigente de várias sociedades esportivas. Eurico Barcellos teve carreira futebolística, sendo "contratado" pelo São Cristóvão. Em geral, tratava-se de gente de estrato médio baixo, moradores do bairro, todos amadores.

Como se pode perceber, avançara rapidamente a estruturação do Irajá Atlético. Em 1918, a comemoração do sexto aniversário foi uma grande festa na qual se promoveram partidas de futebol, bem como páreos de corridas para homens e mulheres. Os jogadores vitoriosos do campeonato de 1917 receberam medalhas e foram aclamados pelo grande público que compareceu à sede $(\mathrm{O}$ FUTEBOL, 28 jul. 1918: 6). O bairro se engalanou para celebrar a conquista de seu representante nas searas esportivas.

Em 1918, houve, contudo, algo curioso. Nas convocações do time, publicadas nos jornais, percebe-se que mudou muito a escalação. Mais ainda, os resultados foram ruins. A equipe campeã em várias ocasiões esteve na "lanterna" do campeonato. O que terá ocorrido?

Alguma cisão houve no Irajá Atlético Clube. Uma parte dos associados, diretores e jogadores, liderados pelo antigo presidente Alcides Horta, deixou a agremiação e fundou o Sport Club Irajá, que se filiou também na Associação Atlética Suburbana, entidade da qual logo se desligou por se julgar injustiçado. 
O problema ocorreu exatamente no jogo entre as duas agremiações do bairro. A vitória do Irajá Atlético parece ter sido o motivo do rompimento. Jogadores e diretores do Sport Club Irajá, especialmente Alcides Horta, contestaram a atuação dos árbitros, desencadeando conflitos que levaram à punição da nova sociedade (FUTEBOL, 13 set. 1918: 8), responsabilizada por atitudes consideradas inadequadas. O Irajá Atlético, ao revés, foi representado como uma associação "em franco progresso", merecedora do "apreço e estima de todos os congêneres e particularmente sua rapaziada, que sabe se distinguir pela sua conduta e civismo" (FUTEBOL, 14 set. 1918: 8).

O Sport Club Irajá, até mesmo por ser dirigido por gente que já conhecia o funcionamento do campo futebolístico, entabulou rápidas ações de estruturação. Os resultados esportivos, contudo, não foram favoráveis. Se o Irajá Atlético acusou a dissidência com a perda de competividade, tampouco foi bom o desempenho da nova agremiação.

Independentemente do aspecto da performance, vale ter em conta o que cercava esse conflito. O bairro crescia, se estruturava, se desenvolvia, em decorrência emergiam também conflitos, discordâncias, desavenças. Não é sequer possível dizer que se tratava, nessa dissidência, de projetos distintos para o bairro. Antes, era mesmo fruto da diversificação societária de Irajá. De toda forma, em 1919, o Sport Club comunicou que estabeleceu sua sede em outra região, em São Cristóvão (FUTEBOL, 28 nov. 1919: 6) ${ }^{15}$.

O Irajá Atlético Clube seguiu sendo o clube mais respeitado do bairro ${ }^{16}$, logo recuperando também seu bom desempenho nos campos. Um indicador relevante é o fato de ter sido convidado para encerrar o festival de comemoração do aniversário do Fidalgo, em 1919, ocasião que contou com a presença de um intendente líder da zona suburbana, Geremário Dantas (EXPEDIENTE..., 15 nov. 1919: 8).

\footnotetext{
${ }^{15}$ A agremiação filiou-se a outra liga, a Associação Carioca de Esportes Atléticos, menos prestigiosa que a Associação Atlética Suburbana, sagrando-se, inclusive, campeã no Torneio Início de 1919 (SPORT..., 11 set. 1919: 10).

${ }^{16}$ No bairro, muitos outros clubes foram fundados no decorrer do tempo, tais como o Bahia Futebol Clube (1919), o Aliados da Pedreira (1925), o Filhos de Irajá Futebol Clube (1934), entre muitos outros.
} 
Outro indício que merece destaque é o reconhecimento da animação de sua torcida. A foto de uma de suas torcedoras, Cacilda Fonseca, futura professora, habituée dos eventos sociais locais, foi publicada no Sport (19 abr. 1919: 4), um periódico esportivo que gozava de respeitabilidade na cidade.

Imagem 3 - Cacilda Fonseca.

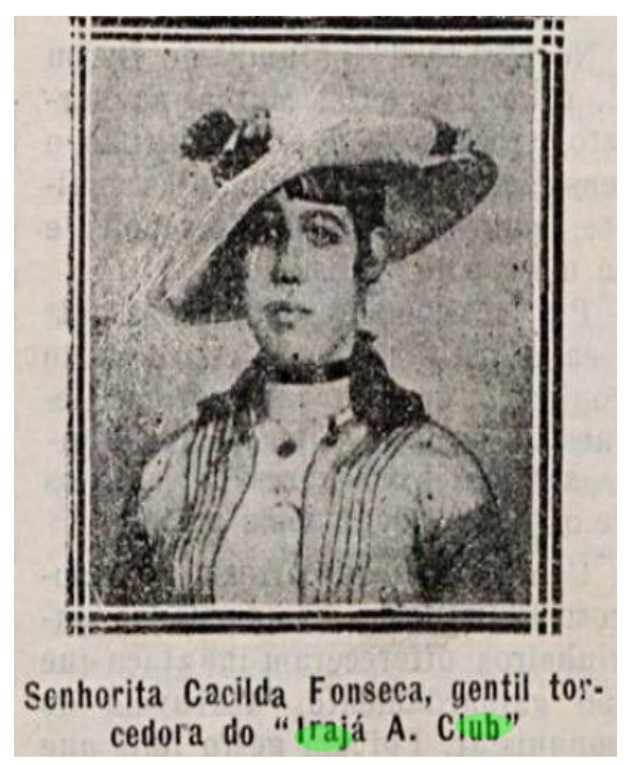

Fonte: Sports, 19 abr. 1919: 24.

Essa repercussão pública das torcedoras tem relação com outro importante movimento do Irajá Atlético: progressivamente se tornou um clube social tanto no sentido de estar atento as reivindicações locais quanto no de promover atividades festivas que contribuíam com a dinamização da vida pública do bairro.

Os bailes da agremiação começaram a ocupar espaço nos jornais, apresentados como exemplo dos progressos do bairro, tendo como um dos indicadores a grande participação feminina, considerada sinal de que se tratava de uma atividade familiar e civilizada ${ }^{17}$. Eram ocasiões suntuosas, a sede sendo muito ornamentada, contando com a presença dos personagens mais renomados da região.

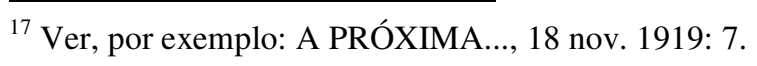


O Irajá Atlético foi consolidando seu nome na cidade, tanto na esfera social quanto na esportiva, em muitas ocasiões considerado "um dos mais fortes grupos" (ESPORTES, 11 abr. 1920: 5) do subúrbio, ainda que não integrasse a prestigiosa Liga Suburbana. Num concurso organizado pelo Jornal das Moças, em 1920 - "Qual o clube de futebol mais querido desta capital?" (10 nov. 1920: 26) - escolha que se dava por voto popular, a agremiação irajaense foi uma das mais citadas.

Frente ao seu sucesso, não surpreende que o cronista do Jornal do Brasil tenha, em 1924, o exaltado por ocasião da comemoração de mais um aniversário. Para ele, "o desporto suburbano está em festa” (FUTEBOL, 24 ago. 1924: 24), pois o Irajá Atlético tratava-se de "um dos seus elementos mais representativos". Elogiando os muitos esforços entabulados para que se mantivesse ativo, assim foi definido: "Grêmio modesto, vivendo unicamente da dedicação de seus sócios, (...), mau grado as vicissitudes porque tem passado, impôs-se à consideração dos esportistas suburbanos por seu próprio valor".

A definição do cronista parece adequada e bem dá conta dos desafios encontrados pelo Irajá Atlético em sua trajetória. Agremiações suburbanas, como o Bangu, Olaria, Mackenzie, Campo Grande, sem falar nos dois iates clubes de Ramos, puderam contar com investimentos da elite local, chegando a aspirar maior participação nos âmbitos esportivos mais prestigiosos da cidade. A sociedade irajaense parece ter tido uma inserção comunitária mais forte, era mais popular, mais dependente de seus sócios. Ainda assim, conseguiu excelentes resultados sociais e esportivos.

No decorrer das décadas de 1920 e 1930, se pode perceber a intensa atividade do Irajá Atlético Clube: participação em campeonatos, promoção de muitos festivais esportivos e torneios internos, organização de bailes e atividades sociais diversas. Sua sede era também eventualmente cedida ou alugada para outras agremiações da região.

A associação se estabilizara como representante do bairro, logrando reconhecimento entre os moradores, ainda que fosse restrito o corpo de associados em função dos custos. Em 1927, a mensalidade passou a ser de 
3\$000 (VIDA..., 2 ago. 1927: 4). Nesse mesmo ano, quando promoveu mais uma reforma na sua sede, o ingresso para seus jogos custava $1 \$ 500$, com entrada franca para as torcedoras (IRAJÁ..., 28 jul. 1927: 5).

Nas mesmas edições desses jornais citados, pode-se ver que uma poltrona para um espetáculo no Teatro João Caetano custava $6 \$ 000$, enquanto no São José valia 20\$000. Na feira livre, um quilo de açúcar estava tabelado a $1 \$ 300$, enquanto um quilo de arroz entre $1 \$ 200$ e $1 \$ 600$ (FEIRAS..., $14 \mathrm{dez}$. 1928: 13). Os valores do Irajá Atlético, portanto, não eram assim tão elevados, mas certamente eram agentes dificultadores para algumas famílias.

Deve-se considerar que, no decorrer dos anos 1920, o bairro teve um novo fluxo de crescimento populacional em função do loteamento e venda de vários terrenos, com destaque para a construção da Sociedade Condomínio Irajá (RODRIGUES, 2012). É provável que isso tenha se refletido no aumento da base societária do Irajá Atlético. Tal mudança talvez ajude a entender novas tensões internas que ocorreram em 1927, quando "um numeroso grupo de valorosos associados (...), desejosos de reerguerem o clube a altura de suas gloriosas tradições, (propuseram) à assembleia medidas capazes de impulsionar a vida do clube" (VIDA..., 5 abr. 1927: 4).

O Irajá passou a ter como presidente o já citado Manoel Antunes Baptista. Outro articulador da iniciativa foi Antonio Affonso Cardoso, importante comerciário e proprietário da Pedreira Irajá. Cypriano de Carvalho era um dos mais antigos associados. Edgard Figueira atuava junto com o primeiro nas iniciativas de imprensa que cobriam os subúrbios do Rio de Janeiro.

Essa mudança parece ter dinamizado o cotidiano do clube, tornando-se mais frequentes as atividades sociais, como bailes e tardes dançantes, bem como torneios internos de dama e tênis de mesa. Isso não significou a redução da faceta pública do Irajá, garantida por suas participações constantes, muitas vezes com sucesso, nos campeonatos da Associação Atlética Suburbana.

Aparentemente, o clube adotou um comportamento mais cortês, mais cavalheiresco. Passou, por exemplo, a fazer recepções às equipes adversárias 
que o enfrentavam no campo da Monsenhor Félix. Outro indicador interessante é o aumento de sua participação em datas especiais de outras ligas. Em 1928, por exemplo, honrou uma grande festividade promovida pela Liga Gráfica de Esportes, uma curiosa entidade que contava com muitas agremiações ligadas a empresas de imprensa (OS ESPORTES..., 24 nov. 1928: 8).

Percebe-se também maior preocupação em regular o comportamento da torcida, como explícito num informe sobre um festival esportivo promovido no campo da agremiação: "não serão permitidas manifestações hostis aos juízes e serão postos fora de campo os que se portarem inconvenientes" (FUTEBOL..., 10 nov. 1928: 7). Tudo leva a crer que havia um movimento inspirado no que se passava em outros clubes da cidade, mais ciosos de adotar posturas mais comedidas, algo que nem sempre era respeitado pelos torcedores.

Um novo passo se deu quando o Irajá passou a integrar, em 1930, a mais prestigiosa Liga Metropolitana de Desportos Terrestres (OS ESPORTES, 13 jan. 1930: 7), naquele momento esvaziada por os grandes clubes da cidade estarem integrando a Associação Metropolitana de Esportes Atléticos, mas ainda assim superior à Associação Atlética Suburbana.

A essa altura, já fora fundada nas redondezas uma agremiação de perfil bastante distinto: o Guanabara Tênis Clube.

\section{Guanabara Tênis Clube: uma estratégia comercial}

Na Freguesia de Irajá, houve uma importante propriedade pertencente ao Visconde de Brás de Pina, dedicada à plantação de cana - com produção de açúcar e aguardente, bem como ao benefício da pesca da baleia, aproveitando a área de mar do terreno.

Depois de ser dividida e de passar pelas mãos de diferentes proprietários, nos anos 1920, numa dessas glebas, a Companhia Imobiliária Kosmos, pertencente aos Guinle, lançou um empreendimento imobiliário de alto padrão, a Vila Guanabara. A exemplo das experiências de cidade-jardim de Richard Parker (SILVA; BERLINI, 2015), se tratava de um bairro modelo, 
planejado com vários confortos, inclusive uma agremiação esportiva: o Guanabara Tênis Clube.

O Guanabara Tênis Clube já nasceu, em 1929, com uma boa estruturação, inserido na ambiência que marcou a Vila Guanabara. Ainda que indicasse uma modalidade prioritária em sua denominação, pretendia também estimular a prática do "basquetebol, voleibol e saltos" (FUNDAÇÃO..., 30 nov. 1929: 8), fazendo uso de previstos ginásio e piscina. A ideia que levou à criação do "elegante centro de reunião" (GUANABARA..., 9 out. 1929: 17) era reunir a elite local. Não surpreende a intenção quando sabemos que Brás de Pina era apresentado como a "Ipanema da Leopoldina" (MUNDANIDADES, 21 nov. 1929: 3).

Imagem 4 - Propaganda da Vila Guanabara.

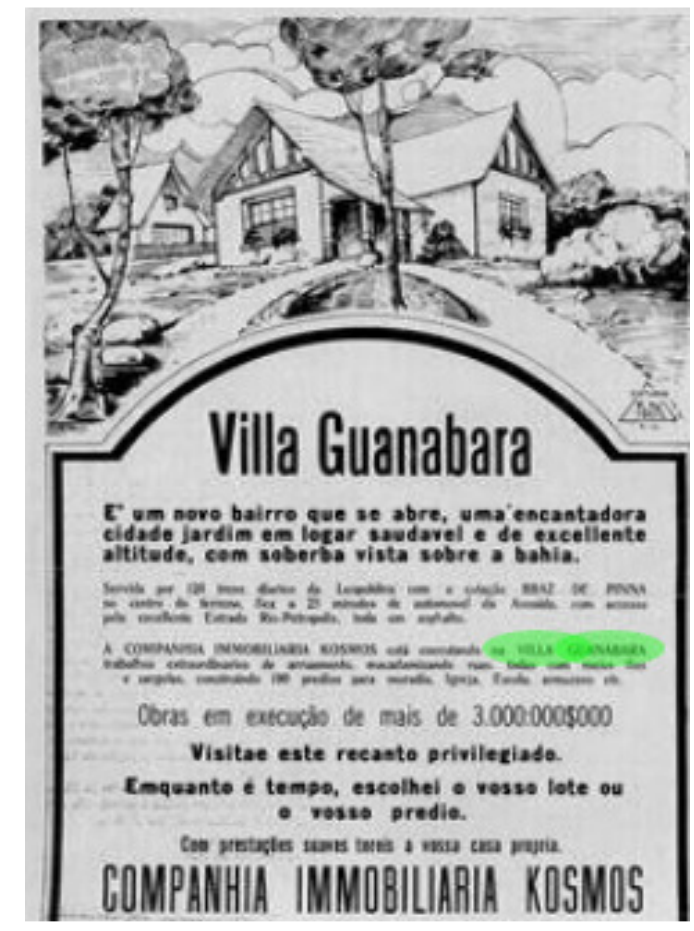

Fonte: Revista da Semana, 2 mar. 1929: 4.

O perfil dos fundadores ajuda-nos a perspectivar o padrão da iniciativa. Um deles foi o jornalista, literato e político Carlos Maul. Outro foi o notório advogado e banqueiro Oscar Sant’anna, diretor da Imobiliária Kosmos. Emilio 
Alcoforado e Jorge Vidal eram engenheiros também ligados à construção da Vila Guanabara, bem como empreendedores em outros bairros da cidade ${ }^{18}$.

Não surpreende que a iniciativa tenha recebido tanta atenção e incentivo por parte dos meios de comunicação. Se o Irajá Atlético foi paulatinamente logrando maior reconhecimento público, articulando-se com um projeto de valorização do bairro, o Guanabara Tênis Clube já surgiu como expressão da representação de Brás de Pina, considerado "dos mais lindos da Capital" (TODOS, 2 nov. 1929: 8), "um suntuoso subúrbio".

$\mathrm{Na}$ verdade, o clube era apresentado como um dos atrativos da Vila Guanabara, mais o fruto de uma estratégia comercial do que de articulação comunitária. A Imobiliária Kosmos, a fim de promover seu empreendimento, usualmente organizou, nos salões da agremiação, almoços para receber a imprensa e importantes personagens da cidade. Tratava-se de uma associação totalmente distinta do Irajá Atlético não somente pelo padrão econômico dos envolvidos, como também pela dinâmica de funcionamento.

Entre muitas festas e eventos sociais promovidos desde os meses iniciais de funcionamento, em 1930, o Guanabara começou a organizar suas primeiras atividades esportivas: jogos de tênis. Nesse mesmo ano, foi convidado para festivais de agremiações de perfil semelhante, como o Grajaú Tênis Clube (TÊNIS, 6 nov. 1930: 12). Essa sociedade, aliás, retribuiu as muitas visitas, disputando torneios em Brás de Pina, ocasiões cercadas de elogios à amabilidade dos anfitriões e boa qualidade das instalações ${ }^{19}$.

O Grajaú tinha muitas similaridades com a Vila Guanabara. Tratou-se de um projeto imobiliário executado pela Companhia Brasileira de Imóveis e Construções, de propriedade de Antônio Eugênio Richard Júnior. O perfil societário dos moradores era semelhante ${ }^{20}$. O Grajaú Tênis Clube também surgiu, em 1925, no bojo das iniciativas do empreendimento.

Note-se que as relações do Guanabara Tênis não eram com o subúrbio, mas sim com as zonas privilegiadas do Rio de Janeiro. O Grajaú Tênis tornou-

\footnotetext{
${ }^{18}$ A lista de fundadores e primeiros diretores foi publicada em: ÚLTIMAS..., 15 jan. 1930: 5.

${ }^{19}$ Ver, por exemplo: TÊNIS, 19 ago. 1930: 8.

${ }^{20}$ Para mais informações sobre o bairro, ver Leite (2012).
} 
se seu principal parceiro. Os eventos eram sempre marcados por grande festa e celebrações à moda das que nos jornais encontramos descritas quando se tratava das iniciativas das agremiações mais ricas e conhecidas da cidade. Tudo representado como sendo de bom gosto, fartura, requinte ${ }^{21}$.

O Guanabara teve um funcionamento mais restrito. Houve muitos torneios internos de tênis e uma vida social considerável, mas tudo reservado aos associados. Chegou a filiar-se à Federação da modalidade das raquetes, mas sem jamais ter tido destacáveis resultados.

Depois de um início promissor, ainda que muito institucional, ligado à Kosmos, em 1935, o Guanabara Tênis foi dissolvido por "se encontrar inteiramente abandonado pelos sócios e diretores, (...), dado o desinteresse que se revela pelo clube e a sua precária situação econômica" (DIÁRIO..., 7 nov. 1935: 82).

Tudo indica que, alguns anos depois, tenha ocupado o mesmo terreno uma nova agremiação, o Brás de Pina Country Clube, fundado em 1943. Essa sociedade esportiva deixou claro nos estatutos: se envolveria com todos os esportes, mas não com o futebol. Mantinha algo do ar elitista do Guanabara Tênis Clube com o qual não tinha relação de continuidade.

O caso do Guanabara é apresentado como contraponto para que seja possível perceber o quanto a ocupação da região foi heterogênea. Em meio a muitas mudanças no Distrito, o Irajá Atlético também promoveu ajustes no seu funcionamento.

\section{Um novo Irajá Atlético Clube}

Não se pode dizer que a decisão do Irajá Atlético de se filiar à Liga Metropolitana de Desportos Terrestres tenha sido uma decorrência da criação do Guanabara Tênis Clube. Se ambos eram dirigidos por gente da elite, o primeiro o era por moradores mais antigos do bairro, alguns desses ligados aos negócios locais, enquanto o segundo por profissionais liberais que tinham

${ }^{21}$ Ver, por exemplo: AS FESTAS..., 11 out. 1931: 14. 
recentemente se instalado na região em função da Vila Guanabara. Se o primeiro tinha em conta uma inserção mais intensa no Distrito, o segundo era de caráter mais restrito. São indicadores de distintos momentos e movimentos de urbanização.

A ligação a uma entidade futebolística mais prestigiosa teve a ver mesmo com movimentos internos do Irajá Atlético, uma maior ambição no que tange à projeção na cidade. A essa altura, era presidente Alcebíades Fontenelle, "figura bastante conhecida nos esportes dos subúrbios, já tendo mais de uma vez desempenhado postos salientes em vários clubes suburbanos" (O IRAJÁ, 26 ago. 1930: 6). Ferroviário e importante liderança sindical, era um líder suburbano de estrato médio.

Perceba-se que o Irajá Atlético também se filiou à Associação Carioca de Esportes Atléticos, entidade na qual Alcebíades Fontenelle ocupava cargo de direção. Essa liga foi, na verdade, fruto da fusão da Associação Atlética Suburbana com a Liga Leopoldinense de Futebol. Pretendia não somente organizar campeonatos de futebol, como também de basquete, vôlei, tênis, atletismo, ciclismo, entre outros.

Em 1931, o Irajá Atlético filiou-se à Liga Brasileira de Desportos (O IRAJÁ..., 30 abr. 1931: 2), àquela altura uma subliga que se transferiu da Liga Metropolitana para a Associação Metropolitana de Esportes Atléticos. Nesse cenário, anunciou o intuito de aumentar o escopo de modalidades com as quais pretendia se envolver. Para tal, a diretoria aventou construir uma nova sede mais ampla e confortável na Avenida Automóvel Clube (NA LIGA..., 4 abr. 1931: 3).

Um indicador de que se ampliaram os intuitos do Irajá Atlético e de que se alinhara a algumas ações das mais importantes agremiações da cidade foi ter se aproximado do escotismo. Essa foi uma regularidade nos anos 1920-1940, tanto nas regiões sul e central (o mesmo se observou com o Flamengo, Botafogo, especialmente o Fluminense) quanto nos subúrbios (com o Mackenzie, o Jequiá, notadamente o Olaria). 
Herold e Melo (2018) demonstraram que muitas agremiações do Rio de Janeiro estabeleceram, em diferentes graus, relações com os grupos de escoteiros. Tratava-se de uma maneira de demonstrar compromissos com a educação da juventude, algo valorizado no cenário nacional do momento. Essas iniciativas fortaleciam a base social e contribuíam com a difusão de uma boa imagem dos clubes, o forjar de uma positiva representação ao explicitar seu envolvimento com as questões relevantes do bairro, da cidade, da nação.

Em 1931, no clube foi fundada a primeira associação de escoteiros do Irajá, uma iniciativa da Federação Suburbana de Escoteiros com apoio da Associação de Escoteiros de Cascadura (ASSOCIAÇÃO..., 7 mar. 1931: 13). Assumiu a chefia da tropa João Ignácio dos Santos, ferroviário, na época um dos mais notáveis líderes do escotismo na cidade (QUAL..., 13 abr. 1930: 10). O subchefe era funcionário dos Correios, Atila Fernandes de Amorim. A cerimônia inaugural contou com a presença de grande público, diretores do Irajá Atlético, lideranças do movimento a celebrar que surgia "uma forte agremiação escoteira no poderoso grêmio esportivo" (ASSOCIAÇÃO..., 27 fev. 1931: 10).

A diretoria, na época liderada por Carmindo da Cunha, apoiou enfaticamente a iniciativa em função de compartilharem a ideia de mens sana in corpore sano (ASSOCIAÇÃO..., 14 fev. 1931: 11). O grupo de escoteiros trouxe novos frequentadores para o Irajá Atlético, um grupo disposto a cultuar a prática de exercícios físicos com um fim mais diretamente relacionado à saúde. A sede da agremiação passou a acolher festivais do movimento nos quais havia demonstrações diversas de ginástica. Ao mesmo tempo, o nome da sociedade irajaense passou a circular ainda mais na cidade.

Parecia alvissareiro o futuro do Irajá Atlético às vésperas de suas duas décadas de existência. O clube sentiu, todavia, o impacto de sua decisão de ampliar sua atuação no âmbito futebolístico: o incremento dos custos, inclusive porque os jogos eram realizados em área bem maior da cidade; o maior rigor no 
cumprimento das regras ${ }^{22}$; o aumento das exigências no que tange a equipamentos e instalações; a cobrança mais intensa da observância da regra do amadorismo, o que no caso das agremiações de subúrbio, em muitas ocasiões, foi um problema em função da sua formação societária ${ }^{23}$.

Foi, de fato, intenso o debate que cercou a adoção do profissionalismo no futebol, deixando explicitar as mais diversas tensões de classe que cercavam a prática do esporte na cidade. Na verdade, essa discussão pode ser observada em outros estados e mesmo países, marcando a transição de um modelo de esporte mais aristocrático para outro mais burguês, no sentido de que mais explicitamente passa a se articular com padrões de consumo e espetáculo. $\mathrm{Na}$ mesma medida, consagra a maior presença dos populares no âmbito da prática da modalidade, não somente na assistência ${ }^{24}$.

Algo desses impactos ficou claro em um conflito ocorrido, em 1931, num jogo disputado contra a Portuguesa. Segundo o delegado, houve "um verdadeiro sururu entre jogadores e torcedores" que descambou em tiros, facadas e correria generalizada (AS QUESTÕES..., 17 maio 1931: 7). A agremiação irajaense foi muito criticada pelo comportamento de seus torcedores.

$\mathrm{Na}$ verdade, na mesma medida em que cresceu a visibilidade do clube na cidade, em função de sua maior presença nos campeonatos mais reconhecidos, também aumentou o número de críticas. A diretoria se empenhava em defender a agremiação e contestar as acusações, não poucas vezes partindo para o ataque.

No citado conflito, além de contestar que o clube tenha sido culpado pelos incidentes, a diretoria do Irajá se mostrou indignada com as críticas a seu campo, julgado não plenamente adequado aos campeonatos da nova liga. Carmindo da Cunha argumentou que a agremiação cumpria todas as exigências,

${ }^{22}$ Por exemplo, em função de conflitos ocorridos numa partida disputada com o Oriente Atlético Clube, de Santa Cruz, um de seus jogadores foi excluído da competição (JORNAL do Comércio, 11 jul. 1930: 8).

${ }^{23}$ A diretoria do Irajá Attético chegou a eliminar jogadores para que fosse observada a regra que impedia a participação de quem trabalhasse nas chamadas "profissões braçais" (ver, por exemplo: UM..., 20 jun. 1931: 6).

${ }^{24}$ Para um debate sobre o tema, ver o livro organizado por Gomes e Pinheiro (2015). 
inclusive o terreno gramado, coisa que não ocorria com outras sociedades que não eram admoestadas (IRAJÁ A., 31 mar. 1931: 11).

De forma sutil, o dirigente supôs a existência de algum preconceito por trás do que julgava ser um desrespeito flagrante. Deixou transparecer que considerava que as críticas tinham relação com sua origem humilde, o que não o impedia de ter "mais de cinco centenas de filiados, uma existência que vai por quase duas décadas e uma modesta sede". Independentemente dos méritos, o Irajá enfrentava e combatia os estigmas que pareciam seguir se manifestando acerca dos subúrbios.

De outro lado, a diretoria assumiu, em algumas ocasiões, que sua torcida era "quente", tendo que ser controlada em seus impulsos. Nos anúncios de seus jogos, não era raro inserir a informação de que "não consentirá em absoluto qualquer manifestação hostil aos jogadores, juízes ou quem quer que seja e expulsará do campo todo aquele que agredir as ordens acima referidas".

O Irajá se equilibrava entre as peculiaridades locais, das quais se julgava representante, e as cobranças oriundas da região central, às quais criticava, mas tentava respeitar não somente para seguir fazendo parte de um cenário maior, como também porque, em certa medida, acreditava integrar seu projeto civilizatório, algo que se extrapolava para o bairro.

$\mathrm{Na}$ verdade, estava prestes a se iniciar uma nova fase no futebol carioca. Em breve, o profissionalismo, mesmo que polêmico, tornar-se-ia uma realidade e, ao fim e ao cabo, deixaria mais claras as diferenças socioeconômicas. Foram anos turbulentos, com muitas mudanças e criações de novas ligas. Em 1937, a Liga de Futebol do Rio de Janeiro unificou muitas entidades. Em 1941, transformou-se em Federação Metropolitana de Futebol. A prática amadora se manteria, mas perderia espaço.

O Irajá tentou a todo momento se posicionar estrategicamente no meio de tamanha confusão. Mais do que tudo, enfrentava dificuldades operacionais para permanecer nos campeonatos mais exigentes. A despeito disso, seguiu 
sendo um clube muito popular ${ }^{25}$, ainda que jamais integrando as principais divisões das mais prestigiosas entidades esportivas.

Manteve sua intensa vida social, articulada com os acontecimentos do bairro. Foi, por exemplo, a sede do concurso da Princesa de Irajá, uma disputa ligada aos Jogos da Primavera. Com "a presença de uma multidão delirante de entusiasmo e sob milhares de aplausos" (FESTA..., 10 set. 1934: 1), em 1934, Dulcineia Bianchi foi a escolhida.

Imagem 5 - Dulcineia Bianchi, Princesa do Irajá.

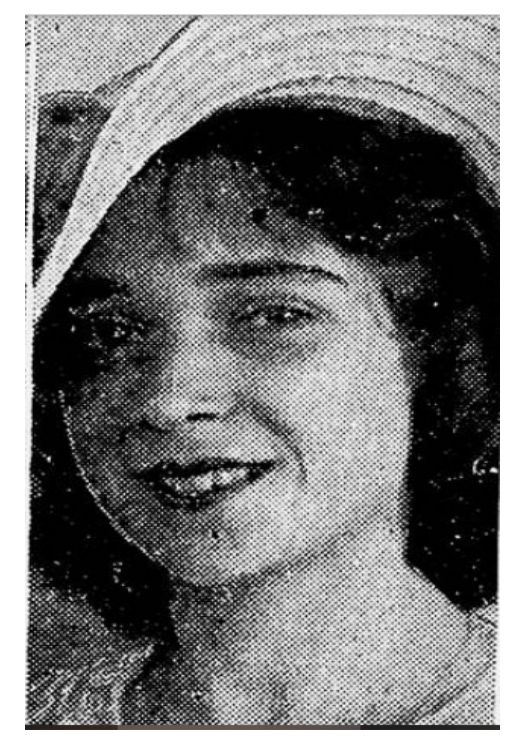

Fonte: Diário da Noite, 8 set. 1934: 1.

Essas disputas mobilizavam a cidade ${ }^{26}$, as escolhidas gozando de certa notoriedade. Representavam com garbo a suposta expressão da beleza local. De cada bairro, um clube acolhia o concurso. O Irajá Atlético foi o indicado para tal, um sinal de que seguia reconhecido como espaço de organização das ações notáveis da região.

Há de se ter em conta que, a partir da $2^{\mathrm{a}}$ metade dos anos 1930, houve um grande desenvolvimento da vida festiva irajaense. Um dos indicadores mais notáveis desse processo foi a inauguração de várias salas de cinema na região:

\footnotetext{
${ }^{25}$ Ver, por exemplo, resultado do concurso de popularidade promovido pelo Jornal dos Sports (31 maio 1934, p. 2). A essa altura, o Irajá estava na $2^{a}$ divisão da AMEA.

${ }^{26}$ Ver, por exemplo: FESTA..., 27 mar. 1934, p. 1 e 3.
} 
em Brás de Pina (Santa Cecília e Brás de Pina, ambos de 1937), em Vaz Lobo (Vaz Lobo, 1940), Ramos (Rosário, 1938), Irajá (Triunfo, 1936, e Irajá, $1941)^{27}$.

Além disso, nos anos 1940, outras agremiações de naturezas distintas foram criadas no bairro. Uma das mais ativas foi o Irajá Club Dancing, que animou a vida social local com muitos bailes (SOCIEDADES..., 12 dez. 1941: 11). Com linha de atuação semelhante, havia o Irajá Recreativo Clube (UM GRANDE..., 19 set. 1942: 6). Foram fundadas, inclusive, novas agremiações dedicadas ao velho esporte bretão, entre as quais o Irajá Futebol Clube.

Até essa altura, a despeito dos intuitos anunciados em seus estatutos, o Irajá Atlético não se envolvera profundamente com outra modalidade que não o futebol. Somente quando o relacionamento com o velho esporte bretão começou a ficar mais difícil, se percebe o incentivo ao futebol de salão, que se tornava conhecido e praticado em muitos clubes da cidade, inclusive dos subúrbios (FEDERAÇÃO..., 10 mai. 1935: 3).

Havia motivos para tal. Era menos custoso por envolver menor número de atletas e requisitar instalações mais fáceis de manter (a despeito de, por vezes, mais caras para construir). Além disso, um ginásio poderia ser usado para várias modalidades, ao contrário de um campo de futebol. O Irajá Atlético logo se filiou à Federação Metropolitana de Desportos, disputando o grupo B do campeonato de futebol de salão.

Nos anos 1940, vemos o Irajá Atlético se dedicando a outras modalidades, tais como o basquetebol e o tênis de mesa. Com as mudanças no âmbito futebolístico, a partir de 1938, o clube deixou, em definitivo, de fazer parte das ações mais notáveis da cidade. Não se profissionalizando, continuou a praticar o ludopédio nas ligas e departamentos amadores, alguns deles circunscritos aos subúrbios, como a Federação Atlética Suburbana.

Durante décadas, o Irajá Atlético participou dessas iniciativas, mas naqueles anos finais da década de 1930 estava mesmo se encerrando uma importante fase agremiação. Perceba-se que, nesse momento, os campeonatos

${ }^{27}$ Para mais informações, ver Sousa (2013) e Sousa (2014). 
do subúrbio eram denominados, com explícito estigma, de contendas do "esporte menor". Era pouco para um clube que chegou nos jornais a ser denominado pelo epíteto de "O Glorioso".

Em 1942, uma nota nos jornais chegou a anunciar seu fim. Supostamente, teria perdido seu campo e sua sede social, "onde o esporte suburbano teve os seus dias de glória e satisfação" (DESAPARECEU..., 4 nov. 1942: 9). Assim o cronista terminou o comunicado: "Que surja uma alma salvadora são os nossos votos".

O Irajá não acabou. Tornou-se, mesmo, em definitivo, um clube de bairro, mantendo-se vivo até os dias de hoje. Isso não significa que tenha perdido sua importância, muito pelo contrário. No meio do aumento das desigualdades econômicas no esporte, também manifestas na cidade como um todo, o Irajá encontrou suas estratégias para seguir ativo.

Parece que, mesmo com limites, essas iniciativas têm logrado algum sucesso no decorrer do tempo, tanto assim que pode comemorar o fato de fazer parte dos clubes centenários da cidade do Rio de Janeiro, algo que uma parcela bem pequena das associações cariocas logrou conquistar. A alcunha de "Glorioso" é merecida.

\section{Conclusão}

A criação do Irajá Atlético Clube foi uma expressão de um bairro que progressivamente se estruturava e crescia do ponto de vista populacional. É um desdobramento do processo de diversificação societária, bem como da maior organização das lideranças locais no que tange a iniciativas de desenvolvimento da região, uma estratégia para minimizar a falta de atenção dos poderes públicos.

Mesmo enfrentando divergências internas e a concorrência de outras agremiações, indícios do crescimento da região, o Irajá Atlético conseguiu se legitimar como representante do bairro, envolvendo boa parte da sociedade local em suas atividades, tanto as lideranças que integravam uma elite quanto o 
grande conjunto da população, ainda que esses nem sempre participassem de todas iniciativas.

O Irajá Atlético projetou para a cidade algumas imagens do bairro que contrapunham ideias estigmatizadas, sendo uma demonstração de que nos subúrbios também se aderia a noções de civilização e progresso. Suas ações foram relevantes na produção do espaço, no forjar de uma vocação e um conjunto de representações positivas para uma das mais antigas regiões da cidade que passou por intensas mudanças.

O clube é uma expressão das peculiaridades locais. Não se envolveu com modalidades náuticas, ainda que a região tivesse uma antiga relação com o mar. Da mesma forma, mesmo que tenha sido criada já com aspirações multiesportivas, durante muito tempo somente se manteve aderente ao futebol. No âmbito dessa modalidade, teve poucas ações de inserção nas ligas prestigiosas, assumindo mais explicitamente uma identidade suburbana.

Talvez ajude a entender esse proceder uma formação societária mais claramente de estrato médio, bem como a forte manutenção de bases populares. O caso do Guanabara Tênis Clube ajuda-nos a perceber as diferenças dos grupos sociais que se organizaram na região, ressaltando a heterogeneidade e dinamismo local.

A investigação da experiência do Irajá Atlético Clube nos permitiu lançar olhares para a atuação de grupos que nem sempre recebem a devida atenção nos debates sobre os processos de urbanização do Rio de Janeiro. Cremos ter sido possível, nesse sentido, apresentar algumas compreensões originais sobre o bairro e a cidade.

$\mathrm{O}$ fato de que permanece ativo, mesmo encontrando dificuldades diversas, inclusive aquelas relacionadas aos problemas que acometeram os subúrbios mais recentemente, é um indicador da importância do Irajá Atlético Clube no decorrer do tempo. Discutir algo de sua trajetória é, portanto, também fazer jus às contribuições da agremiação que não equivocadamente foi chamada de "O Glorioso". 
Referências

ABREU, Maurício. A evolução urbana do Rio de Janeiro. Rio de Janeiro: IPLANRIO, 1987.

CANCLINI, Nestor García. Culturas híbridas. São Paulo: Edusp, 1997.

FERNANDES, Nelson da Nobrega. O rapto ideológico da categoria subúrbio. Rio de Janeiro: UFRJ, 1995.

GERSON, Brasil. História das ruas do Rio. Rio de Janeiro: Livraria Brasiliana Editora, 1965.

GOMES, Eduardo de Souza; PINHEIRO, Caio Lucas Morais. Olhares para a profissionalização do futebol. Rio de Janeiro: Multifoco, 2015.

HEROLD JUNIOR, Carlos; MELO, Victor Andrade de. Escotismo e esporte: propostas de educação do corpo no Rio de Janeiro dos anos 1910-1920. Revista Brasileira de Educação, Rio de Janeiro, v. 23, e230045, 2018.

LEFEBVRE, Henry. A produção do espaço. Trad. Doralice Barros Pereira e Sérgio Martins. 2006 (do original: La production de l'espace. 4e éd. Paris: Éditions Anthropos, 2000).

LEITE, Márcia Pereira. Grajaú, memória e história: fronteiras fluidas e passagens. Cadernos Metrópole, São Paulo, n. 5, p. 91-125, maio 2012.

MACIEL, Laura Antunes. Outras memórias nos subúrbios carioca: o direito ao passado. In: OLIVEIRA, Márcio Piñon de Oliveira; FERNANDES, Nelson da Nóbrega (orgs.). 150 anos de subúrbio carioca. Rio de Janeiro: Lamparina/Faperj/EdUFF, 2010. p. 187-218.

MAIA, João Marcelo E. Costa Pinto em dois tempos: os efeitos periféricos na circulação de ideias. Tempo Social, São Paulo, v. 31, n. 2, p. 173-198, 2019.

MELO, Victor Andrade de. Uma geografia do esporte: as experiências dos clubes de iatismo da Zona da Leopoldina (Rio de Janeiro, 1941-1954). GEOUSP, São Paulo, v. 24, n. 1, p. 83-103, 2020a.

MELO, Victor Andrade de. Para o bairro, para o subúrbio, para a nação: a experiência náutica do Olaria Atlético Clube (Rio de Janeiro; 1915-1930). Tempo, Niterói, 2020b. no prelo.

MELO, Victor Andrade de. Novas performances públicas: os clubes athleticos e a educação do corpo (Rio de Janeiro, 1884-1889). Cadernos de História da Educação, Uberlândia, v. 19, n. 3, p. 1051-1068, 2020c. 
MELO, Victor Andrade de. Notas sobre a investigação das experiências de clubes dos subúrbios cariocas. Rio de Janeiro: PPGHC, 2021.

MELO, Victor Andrade de; SANTOS JUNIOR, Nei Jorge. Faces da modernidade: a experiência do Ciclo Suburbano Clube (Madureira/Rio de Janeiro - décadas de 1920-1960). Tempo e Argumento, Florianópolis, v. 12, n. 30, e0202, 2020.

MENDONÇA, Leandro Clímaco. Jornalismo como missão. Tese (Doutorado em História). Niterói: UFF, 2017.

MIYASAKA, Cristiane Regina. Os trabalhadores e a cidade. Tese (Doutorado em História). Campinas: Unicamp, 2016.

NEGRO, Antonio Luigi; SILVA, Sergio (orgs.). E. P. Thompson. Campinas: Editora da Unicamp, 2001.

PECHMAN, Robert Moses. A gênese do mercado urbano de terras. Dissertação (Mestrado em Planejamento Urbano e Regional). Rio de Janeiro: UFRJ, 1985.

RODRIGUES, Agostinho. Meu Irajá. Rio de Janeiro: Instituto Histórico e Geográfico Baixada de Irajá, 2012.

SANTOS, João Casquinha Malaia. Revolução vascaína. Tese (Doutorado em História Econômica). São Paulo: USP, 2010.

SANTOS JUNIOR, Nei Jorge. A vida divertida suburbana. Tese (Doutorado em Estudos do Lazer). Belo Horizonte: UFMG, 2017.

SANTOS JUNIOR, Nei Jorge; MELO, Victor Andrade. Violentos e desordeiros: representações de dois clubes do subúrbio na imprensa carioca (década de 10). Revista Brasileira de Educação Física e Esporte, São Paulo, v. 27, n. 3, p. 411-422, set. 2013.

SILVA, Fernanda Correia; BERLINI, Cíntia Stela Negrão. O acervo pessoal do urbanista Jorge de Macedo Vieira: a importância da preservação do patrimônio documental. Revista Geografia e Pesquisa, Ourinho, v. 9, n. 2, p. 5-13, 2015.

SOARES, Maria Therezinha de Segadas. O conceito geográfico de bairro e sua exemplificação na cidade do Rio de Janeiro. In: BERNANDES, Lysia; SOARES, Maria Therezinha de Segadas. Rio de Janeiro. Rio de Janeiro: Biblioteca Carioca, 1990. p. 105-120.

SOUSA, Márcia Cristina da Silva. Entre achados e perdidos. Tese (Doutorado em Memória Social). Rio de Janeiro: Unirio, 2013. 
SOUSA, Raquel Gomes de. Cinemas no Rio de Janeiro. Dissertação (Mestrado em Ciências). Rio de Janeiro: UFRJ, 2014.

SOUZA, Glauco José Costa. Adiantam-se bastante nos subúrbios. Dissertação (Mestrado em História). Niterói: UFF, 2018.

THOMPSON, E. P. A miséria da teoria. Rio de Janeiro: Zahar, 1981.

\section{Fontes}

A PRÓXIMA soirée do Irajá A. Clube. A Época, 18 nov. 1919, p. 7.

AS FESTAS de aniversário do Grajaú Tênis Clube. Jornal do Comércio, 11 out. 1931.

AS QUESTÕES palpitantes da Brasileira. Jornal dos Sports, 17 maio 1931. ASSOCIAÇÃO Atlética Suburbana. A Noite, 28 fev. 1917.

ASSOCIAÇÃO de Escoteiros de Irajá. Diário Carioca, 14 fev. 1931.

ASSOCIAÇÃO de Escoteiros de Irajá. O Jornal, 27 fev. 1931.

ASSOCIAÇÃO de Escoteiros de Irajá. O Jornal, 7 mar. 1931.

BOND. O Tempo, 30 jul. 1893.

CAMPINHO. Gazeta de Notícias, 28 dez. 1890.

CLUBE Atlético de Irajá. Echo, 18 jun. 1893.

DESAPARECEU o Irajá A. C. Diário Carioca, 4 nov. 1942.

DIÁRIO Oficial da União, 16 fev. 1930.

DIÁRIO Oficial da União, 7 nov. 1935.

DIVERSÕES. O Paiz, 1 dez. 1910.

ESPORTES. A Noite, 11 abr. 1920.

EXPEDIENTE oficial. O Imparcial, 15 nov. 1919.

FEDERAÇÃO Metropolitana de Desportos. O Jornal, 10 mai. 1935.

FEIRAS livre. Correio da Manhã, 14 dez. 1928.

FESTA da Primavera. Diário da Noite, 27 mar. 1934.

FESTA da Primavera. Diário da Noite, 10 set. 1934.

FUNDAÇÃO do Guanabara Tênis Clube. Diário Carioca, 30 nov. 1929.

FUTEBOL. O Imparcial, 16 jan. 1916.

FUTEBOL. O Paiz, 13 set. 1918.

FUTEBOL. O Paiz, 14 set. 1918.

FUTEBOL. Correio da Manhã, 28 nov. 1919.

FUTEBOL. Jornal do Brasil, 24 ago. 1924.

FUTEBOL suburbano. A Manhã, 10 nov. 1928.

GUANABARA Tênis Clube. Jornal do Brasil, 9 out. 1929.

IRAJÁ A. Clube. Diário de Notícias, 31 mar. 1931.

IRAJÁ Atlético Clube. A Rua, 28 jul. 1927.

JORNAL do Comércio, 11 jul. 1930.

MUNDANIDADES. Gazeta de Notícias, 21 nov. 1929.

NA LIGA Brasileira. Jornal dos Sports, 4 abr. 1931.

NOS subúrbios. A Época, 21 ago. 1917.

O CAMPEONATO da Associação Atlética Suburbana. O Imparcial, 21 dez. 1919. 
O FUTEBOL em Madureira. A Razão, 22 jun. 1917.

O FUTEBOL. A Razão, 28 jul. 1918.

O IRAJÁ Atlético Clube tem novo presidente. Diário da Noite, 26 ago. 1930.

O IRAJÁ estreou na Liga Brasileira. Jornal do Sports, 30 abr. 1931.

OS ESPORTES nos pequenos clubes. Diário Carioca, 24 nov. 1928.

OS ESPORTES. A Noite, 13 jan. 1930.

QUAL o clube de futebol mais querido desta capital? Jornal das Moças, 10 nov. 1921.

QUAL o melhor escoteiro do Brasil? Diário Carioca, 13 abr. 1930.

SOCIEDADES recreativas. Jornal do Brasil, 12 dez. 1941.

SPORT. O Echo, 23 jul. 1893.

SPORT. O Imparcial, 30 nov. 1918.

SPORT Club Irajá. O Imparcial, 11 set. 1919.

TEATROS suburbanos. A Imprensa, 30 abr. 1909.

TÊNIS. A Noite, 19 ago. 1930.

TÊNIS. Jornal do Brasil, 6 nov. 1930.

TODOS os esportes. O Jornal, 2 nov. 1929.

ÚLTIMAS notícias. Gazeta de Notícias, 15 jan. 1930.

UM GRANDE acontecimento. Diário da Noite, 19 set. 1942.

UM que foi eliminado. A Batalha, 20 jun. 1931.

VIDA Esportiva. A Rua, 5 abr. 1927.

VIDA Esportiva. A Rua, 2 ago. 1927.

Recebido em: 14 de agosto de 2020

Aceito em: 16 de agosto de 2021 